\title{
Kali czy Nabu? Jaka literatura i jaki nauczyciel będą uczyć rozumienia drugiego człowieka?
}

\section{Kali or Nabu? What kind of literature and what type of teacher will teach understanding the other human being?}

\author{
Anna Janus-Sitarz
Uniwersytet Jagielloński, Kraków
ORCID: 0000-0003-2730-7048
}

\begin{abstract}
The contemporary literature for children and adolescents definitely fulfills its humanistic mission of teaching respect for the Other and understanding the meanders associated with the widespread migration and dilemmas of multiculturalism. Unfortunately the list of old literary works to be read obligatory by students gives no place for Polish teachers to choose all kinds of literature, from many cultures. Furthermore, the new school reading canon underlines the role of books that perpetuate harmful stereotypes. So the crucial question for the Polish researchers is: Should the works of Henryk Sienkiewicz be still read in schools, especially during the rise of nationalist rhetoric? The main challenge for the literature teachers is: How to talk in the classroom about politically incorrect masterpieces? Trying to answer these questions I am presenting the results of my own research on the impact of selected reading of children's literature on the change in the students' approach to literary classics. The differences in the scripts from Sienkiewicz's novel, written by future teachers before reading the story of Jarosław Mikołajewski about a small immigrant and created after such a reading, bring some didactic solutions.
\end{abstract}

Key words: literature teaching, Henryk Sienkiewicz, Jarosław Mikołajewski, stereotypes

Streszczenie: Współczesna literatura dla dzieci i młodzieży zdecydowanie wypełnia swoją humanistyczną misję uczenia szacunku wobec Innego i zrozumienia meandrów związanych z powszechną dziś migracją i dylematami wielokulturowości. Jednak w Podstawie programowej nie ma miejsca na tę literaturę, co więcej, umocniła się klasyka, wobec której wciąż trwają spory, czy nie utrwala groźnych stereotypów narodowych. Kluczowe pytanie dla polskich badaczy brzmi: czy prace Henryka Sienkiewicza powinny być nadal czytane w szkołach, zwłaszcza w okresie narastania retoryki nacjonalistycznej? Głównym wyzwaniem dla nauczycieli literatury jest: jak rozmawiać w klasie na temat arcydzieł niepoprawnych politycznie? Próbując odpowiedzieć na te pytania, przedstawiam efekty badań własnych, dotyczących wpływu wybranej lektury literatury dziecięcej na zmianę w podejściu studentów do klasyki literackiej. Różnice w scenariuszach z powieści Sienkiewicza, pisanych przez przyszłych nauczycieli przed lekturą opowieści Jarosława Mikołajewskiego o małym imigrancie oraz tworzonych po takiej lekturze, przynoszą pewne rozwiązania dydaktyczne. 
Słowa kluczowe: uczenie literatury, Henryk Sienkiewicz, Jarosław Mikołajewski, stereotypy

Współczesna literatura dla dzieci i młodzieży zdecydowanie wypełnia dziś swoją humanistyczną misję uczenia szacunku wobec Innego i zrozumienia meandrów związanych z powszechną dziś migracją i dylematami wielokulturowości. Książki poświęcone młodym bohaterom żydowskim i romskim (Uriego Orleva, Marcina Szczygielskiego, Renaty Piątkowskiej, Magdaleny Kozłowskiej), małym imigrantom (Barbary Gawryluk, Anny Piwkowskiej), uchodźcom (Jarosława Mikołajewskiego, Renaty Piątkowskiej, Zany Fraillon), eurosierotom (Barbary Kosmowskiej, Piotra Rowickiego, Joanny Fabickiej) doskonale tłumaczą młodym przyczyny i konsekwencje nietolerancji i niezawinione dziecięce dramaty.

Niestety, w Podstawie programowej nie ma dla nich miejsca, a na przeładowanych treściami lekcjach - poloniści nie znajdują czasu na literaturę dodatkową. Co więcej, umocniła się klasyka, wobec której wciąż trwają spory, czy nie utrwala groźnych stereotypów narodowych ${ }^{1}$. Na tym tle tym większe znaczenie ma odpowiednie przygotowanie przyszłych nauczycieli literatury, świadomych tego, co i jak czytać z młodymi ludźmi. Realizację tego celu utrudnia sytuacja, w której osoby podejmujące studia polonistyczne same często przesiąknięte są zarówno uprzedzeniami, jak i nacjonalistyczną retoryką.

Co, w takiej sytuacji, można zrobić? Zanim spróbuję poszukać odpowiedzi na to pytanie, przypomnę kilka faktów dotyczących recepcji dawnych arcydzieł, a następnie przedstawię efekty własnego doświadczenia dotyczącego wpływu wybranej lektury literatury dziecięcej na zmianę w podejściu studentów do klasyki literackiej. Wcześniej jednak - kilka niezbędnych założeń.

Po pierwsze, warto zdać sobie sprawę z tego, że obecne pokolenie naszych studentów - przyszłych nauczycieli, to generacja, która sama nie została wychowana na tej tworzonej od dekady znakomitej, mądrej literaturze dla dzieci, uczącej otwartej postawy wobec wielokulturowości, empatii wobec Innego, zwłaszcza słabszego. Tak jak większość praktykujących nauczycieli, tak i nasi studenci nie znają książek o Alku, który radził sobie dzielnie $\mathrm{w}$ getcie pomimo śmiertelnego zagrożenia, o Jaelle, która musiała uciekać z domu podpalonego przez niechętnych Cyganom sąsiadów, o czarnoskórej Sorai, wyśmiewanej przez polskich rówieśników. Sami jako uczniowie nie uczestniczyli w klasowych rozmowach o bohaterach literackich, reprezentujących młodych ludzi z realnego świata: Syrii, Ukrainy, Lampedusy lub warszawskiego getta czy obozu dla uchodźców, potrzebujących pomocy, wsparcia lub po prostu zrozumienia i szacunku. Jeśli tej literatury nie poznają, to nie będą jej czytać ze swoimi uczniami. Tymczasem chyba nigdy dotąd (a przynajmniej od kilku dekad) nie stało przed nami tak duże wyzwanie przygotowania przyszłych nauczycieli potrafiących odróżnić

1 Warto zaznaczyć, że debaty na temat zagrożeń związanych ze statusem literatury w szkole jako części „wielkiej narodowej narracji” miały miejsce w wielu krajach świata (zob. Goodwyn 2012). 
spory z debat politycznych od argumentów na rzecz wychowania dobrego człowieka wrażliwego na losy innych.

Po drugie, należy powrócić do tematu, o którym mówiło się dużo, szczególnie przy okazji zmian programowych, ale na który chyba wciąż nie znajdujemy skutecznego remedium. Chodzi o „skażone arcydzieła” i ich miejsce w szkolnym kanonie. Przypomnę apel Olgi Tokarczuk, wygłoszony na I Kongresie Dydaktyki Polonistycznej w Krakowie, aby usunąć $W$ pustyni i $w$ puszczy z listy lektur ze względu na możliwość destrukcyjnego oddziaływania na dzieci przez utrwalanie negatywnych stereotypów rasowych. W świadomości młodych odbiorców bowiem obraz Afryki kojarzy się z okrutnymi Arabami lub infantylnymi Murzynami, których cechy uosabia komiczna postać Kalego².

Podobne niepokoje wobec arcydzieła wyraża Ryszard Koziołek. Autor zbioru esejów Znakowanie trawy albo praktyki filologii analizuje $W$ pustymi i $w$ puszczy, porównując Sienkiewiczowską powieść do innych, angielskich książek przygodowych dla młodzieży, w których splata się dyskurs kolonialny z inicjacyjnym. Pisze, że na przykład Martin Green (1980) w swej monografii klasycznej literatury przygodowej Dreams of Adventure, Deeds of Empire stawia zdecydowaną tezę, że dziewiętnastowieczna proza tego gatunku była źródłem mitograficznej energii dla brytyjskiego dyskursu imperialnego, utwierdzając w czytelnikach przekonanie o przewadze jakościowej białego człowieka, a twórczość Daniela Defoe (w tym przede wszystkim Robinsona Crusoe) uznaje się za prototyp literackiego imperializmu. Angielscy badacze podkreślają zdecydowany wpływ powieści przygodowej, która „umieszczała bohatera w konkretnej przestrzeni historycznej i geograficznej, gdzie stawał na szczycie rasowej drabiny, a tym samym całego świata" (Koziołek 2011, 133), na chłopięcą wyobraźnię, a także trwałość i siłę kulturowego imaginarium imperialnej tężyzny.

Koziołek dowodzi przynależności autora $W$ pustymi $i w$ puszczy do kolonialnej rodziny europejskich twórców tego gatunku, czego potwierdzenie znaleźć można w jego Listach $z$ Afryki, w których Sienkiewicz dzieli się swoimi refleksjami na temat przyjemności płynącej z poczucia władzy i możliwości rozkazywania mieszkańcom murzyńskich wiosek, w żadnym zaś miejscu nie dostrzega wspólnoty losu historycznego Polaka pod zaborami i skolonizowanego tubylczego mieszkańca Afryki, choć takie kwestie poruszali ówcześni publicyści i politycy.

Autor Ciał Sienkiewicza przypomina, że apogeum tego typu literatury przygodowej dla chłopców zbiega się z kulminacją idei imperialnych, ale jej mit imperialny pozostaje trwały po tym okresie i nadal zajmuje istotne miejsce w narracjach kultury popularnej. „Błędem byłoby - ostrzega zatem badacz - lekceważyć wpływ podobnych opowieści na życie czytelników” (Koziołek 2011, 132).

${ }^{2}$ Szczególnie dobitnie formułuje te zarzuty i obawy Paweł Cywiński (2012, 30). Proponuje on lekturę $W$ pustyni $i$ w puszczy dla zupełnie innego - dojrzalszego - odbiorcy (np. licealisty) i czytanie jej jako historycznego tekstu źródłowego, wymagającego krytycznej analizy. 
Ponawiam więc pytanie, czy dzieło polskiego noblisty, mające ponad 150 wydań i kilkudziesięcioletnią historię obecności w szkole, powinno nadal być obowiązkową lekturą dla współczesnych dziesięcio- czy jedenastolatków. Jeśli uznamy je za szkodliwe, to powinniśmy zdecydowanie domagać się jego usunięcia ze spisu lektur. Ale jeśli wciąż są tacy poloniści, którzy odnajdują w nim wartości niepozwalające zrezygnować z tego tytułu, i jeśli wciąż znajduje ono - wprawdzie radykalnie malejącą - ale jednak grupę młodych czytelników zachwyconych egzotycznymi przygodami Stasia i Nel, to musimy się zastanowić, czy mamy prawo cenzurować dzieło noblisty. Pytanie powinno raczej brzmieć: jak czytać w klasie niepoprawne arcydzieła?

Zanim spróbujemy odpowiedzieć na to pytanie, przypomnijmy, że podobne spory na temat arcydzieł budzących etyczne wątpliwości mają wciąż miejsce $\mathrm{w}$ wielu krajach świata ${ }^{3}$. Jeden z nich opisał Wayne C. Booth (1988) w rozprawie The Company We Keep. An Ethics of Fiction, w której opowiada historię pracującego z nim na tym samym wydziale Uniwersytetu w Chicago młodego czarnego asystenta, który sprzeciwił się prowadzeniu zajęć poświęconych powieści Marka Twaina Huckleberry Finn, ponieważ uznał, że opowieść, w której czarni niewolnicy są ośmieszani, może podsycać nastroje rasistowskie. Booth i inni wykładowcy byli oburzeni i oskarżyli asystenta o brak naukowej obiektywności oraz wystarczających kompetencji, by docenić wartość literackiego arcydzieła. Jednak wiele lat później Booth powrócił do lektury i przyznał, że nie miał racji, lekceważąc obiekcje swego kolegi. Stwierdził, że literatura o dużej sile oddziaływania może mieć destrukcyjny wpływ na czytelnika i nie można jej czytać bezkrytycznie.

Podobne kontrowersje mają miejsce wokół innych światowych arcydzieł. We Włoszech stowarzyszenie Gherush92, zajmujące się walką z wszelkimi formami dyskryminacji, apelowało o wykreślenie Boskiej komedii Dantego z listy lektur szkolnych (zob. Mikołajewski 2012, 12), domagało się krytycznej refleksji nad szkodliwością dzieła, w którym znajdują się treści rasistowskie, islamofobiczne i antysemickie.

Takie same dyskusje odbywają się od wielu lat wokół dzieł Szekspira, a szczególnie Kupca weneckiego - pełnego antysemickich żartów. Jak pisze Piotr Paziński: „od dojścia Hitlera do władzy, do wybuchu II wojny światowej sztuka aż 30 razy gościła na niemieckich scenach" ${ }^{4}$. Komedia popularna była także w polskim teatrze dramatycznym międzywojnia (zob. Marczak-Oborski 1985, 111), do jej czytania zachęcali ponoć narodowcy, traktując ją jak tekst instruktażowy (Paziński 2019).

I choć dramat Szekspira najprawdopodobniej intencjonalnie nie był antysemicki (w Anglii elżbietańskiej właściwie nie było Żydów), a zatem „czcicielem mamony” i „bezlitosnym lichwiarzem” mógł być każdy - również

${ }^{3}$ Szerzej podejmowałam ten temat w artykule Arcydzieła niepoprawne, czyli o potrzebie krytycznego czytania (Janus-Sitarz 2009).

${ }_{4}$ Paziński P., Przypadek Shylocka, http://www.midrasz.home.pl/2002/lis/lis02_01.html [dostęp 10.11.2019]. 
dobry chrześcijanin (zob. Mroczkowski 1966, 173-180), to jednak nie można oddzielić tej sztuki od miejsca i czasu jej wykonywania, od odpowiedzialności inscenizatorów za przewidywalny odbiór widzów, przychodzących do teatru z bagażem własnych doświadczeń w konkretnej rzeczywistości społecznej.

Teraz rzadko wystawia się tę komedię, a jeśli już - to często jako dia$\log \mathrm{z}$ jej kontrowersyjnymi treściami. $\mathrm{W}$ inscenizacjach teatralnych zdarzają się takie kreacje żydowskiego lichwiarza, Shylocka, w których jest on - z jednej strony - przedstawicielem świata wyzysku, z drugiej zaś - ofiarą ostracyzmu ze względu na swoje pochodzenie ${ }^{5}$, czego świadectwem są jego skargi w akcie III dramatu, gdy rozmawiając z Salarinem, żali się, że mu urągano, naigrywano się z jego straty, bluźniono jego narodowi, tylko dlatego, że jest Żydem.

Może zamiast wyrzucać „skażone arcydzieła” z teatrów, księgarń i szkół, lepiej uczynić je inspiracją do refleksji o sprawach wciąż ważnych dzisiaj? A zatem - powracam do pytania: jak czytać z dziećmi $W$ pustyni i w puszczy?

Zrobiłam niewielki rekonesans wśród powszechnie dostępnych cyklów lekcyjnych scenariuszy publikowanych w Internecie przez wydawnictwa zajmujące się pomocami dydaktycznymi dla szkół podstawowych lub portale nauczycielskie. Okazało się, że zdecydowana większość spośród 18, które przestudiowałam, koncentruje się przede wszystkim na podkreślaniu miejsca Sienkiewicza w naszym dziedzictwie narodowym i atrakcyjności egzotycznych przygód Stasia i Nel. Autorzy proponują przy tym szeroki zakres atrakcyjnych metod nauczania. Jednak - z dwoma wyjątkami ${ }^{6}$ - nie znajdziemy w nich żadnego śladu dyskusji na tematy stanowiące przedmiot ogólnopolskiej debaty o kontrowersyjności dzieł Sienkiewicza. Twórcy scenariuszy lekcyjnych pomijają wszelkie niewygodne tematy, takie jak nietolerancja wobec religii czy różnorodność narodowa.

Takie samo zadanie zaprezentowania koncepcji rozmów z 11-latkami o $W$ pustyni i w puszczy dałam dwu grupom studentów specjalności nauczycielskiej. 14 studentów z pierwszej grupy zdecydowanie podążyło śladami swoich byłych nauczycieli i stawiało uczniom te same polecenia i pytania, jakie niegdyś sami słyszeli w szkole:

Za co podziwiamy Stasia?

Opisz kolejne etapy podróży Stasia i Nel.

Opisz egzotyczny świat przyrody w Afryce.

Jakie są różnice między książką a jej filmową adaptacją?

Studenci - przyszli nauczyciele wymyślali wiele bardzo interesujących metod i działań uczniowskich, lecz całkowicie zignorowali jakiekolwiek kontrowersyjne tematy.

5 Taka np. była koncepcja opery Kupiec wenecki Andrzeja Czajkowskiego w reżyserii Keitha Warnera w warszawskim Teatrze Wielkim - Operze Narodowej (premiera 24 X 2014). Zob. https://dzieje.pl/kultura-i-sztuka/kupiec-wenecki-w-teatrze-wielkim-operze-narodowej [dostęp 10.11.2019].

${ }_{6}$ W tym - scenariusz autorstwa Biserki Cejović do gry planszowej $W$ pustyni $i$ w puszczy. Zob. Materiały zamieszczone na stronie wydawnictwa Agencja Promocyjna OKO Iwona Haberny: http://sienkiewicz.promocjaksiazki.pl/karta/k36ir/ 
To samo zadanie postawiłam przed drugą grupą studentów, tyle że tym razem ich prace poprzedzone były lekturą współczesnej opowieści Wędrówka Nabu Jarosława Mikołajewskiego ze znakomitymi ilustracjami Joanny Rusinek. Przypomnę, że główna bohaterka tej przejmującej historii, mała dziewczynka, Nabu, jest ofiarą bliżej niekreślonej wojny. Nie wiemy, kto podpalił jej piękny i ciepły dom, w którym była szczęśliwa, miała rodzinę i marzenia. Nie wiemy, kto potem podpalił całą wioskę. Oczami małej dziewczynki poznajemy etapy jej ucieczki z domu, „którego nie było”, w poszukiwaniu miejsca, „gdzie nie palą się domy”. W na pół realistycznej, na pół metaforycznej podróży Nabu napotyka nieistniejące ściany: granice, druty kolczaste, morza, które są strzeżone przez nieprzyjaznych jej ludzi: żołnierzy, policjantów, celników. Nie chcą jej przepuścić, bo - żeby być po drugiej stronie - trzeba się tam urodzić. Nabu nie rozumie absurdalnych zakazów ludzi, którzy nią gardzą, którzy się z niej wyśmiewają. Kiedy na przekór wszelkim trudnościom i cierpieniom dociera na tę „drugą stronę”, spotyka ludzi, z których połowa uśmiecha się do niej i wskazuje domy, druga zaś połowa rzuca jej złowrogie spojrzenia i wskazuje morze - powrotną drogę. Przez nagłą zmianę czasu przeszłego na teraźniejszy książka nakazuje czytelnikom opowiedzieć się po jednej z tych dwu grup.

Przeczytałam tę krótką opowieść z grupą studentów tak, jak czytałabym ją z dziećmi: siedzieliśmy w kole, czytając głośno, jeden po drugim. Przekazywaliśmy sobie książkę, aby każdy mógł odczytać jedną stronę, a potem pokazać innym ilustrację. Nie komentowaliśmy tej lektury. Tylko przeczytaliśmy. Tydzień później studenci otrzymali zadanie napisać scenariusz lekcji poświęconej $W$ pustyni i w puszczy.

Trudno nie zauważyć znaczącej różnicy między projektami grupy, która tworzyła scenariusze o Sienkiewiczowskiej powieści po przeczytaniu współczesnej książeczki o doświadczonej przez los, ale wytrwale dążącej do celu Nabu, i tej grupy studentów, którzy pisali konspekty bez takiego przygotowania. Okazało się, że ta uprzednia lektura rozwijająca empatię miała ogromny wpływ na zrozumienie potrzeby krytycznego czytania niepoprawnego - z punktu widzenia współczesnych norm etycznych - literackiego arcydzieła. W każdym z tych kilkunastu scenariuszy pojawiły się różnorodne pomysły na działania prowadzące do refleksji i krytycznej lektury.

Studenci proponowali realizację pewnych zadań przed przystąpieniem do lektury, takich jak na przykład:

- Małe grupowe projekty na temat rasizmu i jego konsekwencji;

- Wywiady przeprowadzane przez dzieci z członkami rodziny o stereotypach Polaka i Murzyna;

- Dyskusje o szkodliwości negatywnych stereotypów narodowych;

- Dyskusje o zmianach, jakie nastąpiły w ciągu wieku w myśleniu o tolerancji;

- Wprowadzenie do historycznego kontekstu, aby uczniowie mieli świadomość, jakie poglądy dominowały w czasach Sienkiewicza. 
Proponowano zadania sprzyjające krytycznemu czytaniu, takie jak na przykład:

- Podczas czytania zaznaczaj fragmenty, które są nie do zaakceptowania z punktu widzenia współczesnego człowieka.

Pojawiały się takie pomysły na lekcyjne działania, jak:

- charakterystyka czarnoskórego bohatera, Kalego, z punktu widzenia XIXwiecznego narratora i współczesnego człowieka;

- inscenizacje scen z książki, rozwijających empatię i uświadamiających uczniom, że inny nie są gorsi.

Ciekawe były także proponowane zadania domowe. Przykładowo:

- Wyobraź sobie, że jesteś Kalim i przyjeżdżasz do Polski. Opisz, jak witają cię ludzie.

- Zapisz po trzy przykłady, które podobają ci się w polskiej i afrykańskiej kulturze.

- Napisz list do Kalego, opisując, co podobało ci się w jego zachowaniu, i oferując mu przyjaźn.

- Napisz kartkę z pamiętnika Kalego. Opisz swój kraj i swoje zainteresowania.

- Gdybyś był(a) Sienkiewiczem, co zmieniłbyś/zmieniłabyś w jego powieści?

Okazało się zatem, że uprzednia lektura utworu rozwijającego empatię wobec Innego miała istotny wpływ na rozumienie przez studentów potrzeby krytycznego czytania klasycznego dzieła. Sądzę, że podobna kolejność w czytaniu książek, najpierw - współczesnych, później kanonicznych klasyków, może być wykorzystana również wobec uczniów. Może niech Nabu nauczy ich czytać $W$ pustyni i $w$ puszczy?

Mam nadzieję, że powyższy przykład z uniwersyteckiej praktyki - choć w pewnej mierze - wskazuje, jaki wpływ na uświadomienie sobie przez przyszłych szkolnych polonistów ich odpowiedzialności za kształcenie postaw młodych ludzi mogą mieć dokonywane przez nauczycieli akademickich wybory lektur i sposobów ich czytania.

\section{Bibliografia}

Booth Wayne C., 1988, The Company We Keep. An Ethics of Fiction, Berkeley.

Cywiński Paweł, 2012, „W pustyni i w puszczy” nie dla dzieci, „Gazeta Wyborcza" 9-10 czerwca.

Goodwyn Andrew, 2012, The Status of Literature: English Teaching and the Condition of Literature Teaching in Schools, „English in Education” 46 (3).

Green Martin, 1980, Dreams of Adventure, Deeds of Empire, London.

Janus-Sitarz Anna, 2009, Arcydzieła niepoprawne, czyli o potrzebie krytycznego czytania, w: W trosce dobra edukacje. Teksty dedykowane profesor Jadwidze Kowalikowej, [wyd. zbiorowe pod red. A. Janus-Sitarz], Kraków.

Koziołek Ryszard, 2011, Męskość Stasia w: Znakowanie trawy albo praktyki filologii, Katowice.

Marczak-Oborski Stanisław, 1985, Teatr polski w latach 1918-1965. Teatry dramatyczne, Warszawa. 
Mikołajewski Jarosław, 2010, Dante na cenzurowanym, „Gazeta Wyborcza”, 20 marca.

Mroczkowski Przemysław, 1966, Szekspir elżbietański i $\dot{z} y w y$, Warszawa.

Paziński Piotr, Przypadek Shylocka, http://www.midrasz.home.pl/2002/lis/ lis02_01.html [dostęp 10.11.2019].

\section{O Autorce}

Anna Janus-Sitarz - profesor w Katedrze Polonistycznej Edukacji Nauczycielskiej na Wydziale Polonistyki Uniwersytetu Jagiellońskiego w Krakowie; kieruje Centrum Badań Edukacyjnych i Kształcenia Ustawicznego. Inicjatorka Kongresów Dydaktyki Polonistycznej; redaktor naukowa serii wydawniczej „Edukacja Nauczycielska Polonisty”. Autorka książek: Groteska literacka. Od diabła w Damaszku po Becketta i Mrożka; Lekcje teatru; Przyjemność i odpowiedzialność w lekturze. O praktykach czytania literatury $w$ szkole; $W$ poszukiwaniu czytelnika. Diagnozy, inspiracje, rekomendacje; współautorka podręczników: Barwy epok i Lustra świata. 